\title{
PERLAKUAN SISTEM OLAH TANAH DAN APLIKASI URIN SAPI TERHADAP PERTUMBUHAN DAN HASIL TANAMAN TERUNG UNGU (Solanum melongena. L.)
}

\author{
Budi Al Hadi $^{(1)}$, Jamilah ${ }^{(2)}$, Abdul Hadi ${ }^{(3)}$ \\ ${ }^{1,2}$ Program Studi Agroteknologi Fakultas Pertanian Universitas Jabal Ghafur - Sigli \\ Email : budi_alhadi@yahoo.com ${ }^{(1)}$,jamilah_unigha@yahoo.co.id ${ }^{(2)}$
}

\begin{abstract}
ABSTRAK
Tujuan dari penelitian adalah untuk mengkaji perlakuan sistem olah tanah dan aplikasi urin sapi terhadap pertumbuhan dan hasil tanaman terung ungu. Penelitian dilaksanakan di kebun warga Kecamatan Tangse Kabupaten Pidie. Bahan yang digunakan adalah urin sapi, benih terung ungu cap panah merah varietas YUMI F1, plastik PE, pupuk kandang, air serta kelengkapan lain dalam menunjang penelitian. Penelitian ini menggunakan Rancanagan Acak Kelompok (RAK) pola faktorial, yang terdiri dari 2 faktor yaitu faktor pertama sistem olah tanah (T) yang terdiri dari 3 taraf; $\mathrm{T}_{0}=$ tanpa olah tanah, $\mathrm{T}_{1}=$ olah tanah minimum, $\mathrm{T}_{2}=$ olah tanah konvensional, dan faktor kedua aplikasi urin sapi (U) yang terdiri dari 4 taraf; $U_{0}=0 \mathrm{cc} / 1$ air, $U_{1}=20 \mathrm{cc} / 1$ air, $\mathrm{U}_{2}=40 \mathrm{cc} / 1$ air, $\mathrm{U}_{3}=60 \mathrm{cc} / \mathrm{l}$ air. Hasil penelitian menunjukkan sistem olah tanah berpengaruh nyata terhadap tinggi tanaman umur 20 dan 60 HST dan berpengaruh sangat nyata terhadap jumlah buah per plot dan berat buah per plot serta berpengaruh tidak nyata terhadap tinggi tanaman umur 40 HST. Sistem olah tanah yang terbaik dijumpai pada perlakuan sistem olah tanah konvensional. Urin sapi berpengaruh sangat nyata terhadap jumlah buah per plot dan berat buah per plot, berpengaruh tidak nyata terhadap tinggi tanaman. Urin sapi yang terbaik dijumpai pada perlakuan konsentrasi urin sapi $20 \mathrm{cc} / \mathrm{L}$ air.
\end{abstract}

Kata kunci: Sistem olah tanah, urin sapi, terung ungu

\section{PENDAHULUAN}

Terung adalah jenis sayuran yang sangat populer dan disukai oleh banyak orang karena rasanya enak khususnya dijadikan sebagai bahan sayuran atau lalapan. Selain itu terung juga mengandung gizi yang cukup tinggi, terutama kandungan vitamin A dan fosfor. Komoditas terung ini cukup potensial untuk dikembangkan sebagai penyumbang terhadap keanekaragaman bahan sayuran bergizi bagi penduduk (Firmanto,2011).
Menurut hasil penelitian (Sunarjono, 2013) bahwa setiap 100 gr bahan mentah terung mengandung 26 kalori, 1 gr protein, 0,2 gr hidrat arang, 25 gr vitamin A, 0,04 gr vitamin B dan 5 gr vitamin C. Selain itu, terung juga mempunyai khasiat sebagai obat karena mengandung alkaloid, solanin dan solasodin. Terung ungu yang mudah didapatkan ini banyak mengandung serat dan vitamin B1, B3 dan B6. Selain itu terung ungu juga mengandung asam Chlorogenic. 
JAR,Volume 4 Nomor 1 April 2021

p-ISSN 2615-417X, e-ISSN 2721-0782

DOI : https://doi.org/10.47647/jar

Asam Chlorogenic adalah tergolong salah satu sayuran yang bebas dari hama serangga yang biasanya terdapat pada sayuran.

Urin sapi dapat menjadi pupuk cair bagi tanaman karena banyak mengandung senyawa yang larut dalam air yang dapat menyuburkan tanah dan tanaman. Selain itu urin sapi yang digunakan akan menyebabkan persediaan unsur hara menjadi lebih baik karena urin sapi mengandung persenyawaan dalam bentuk yang larut yang dikeluarkan oleh ginjal sapi (Nazaruddin, 2001).

Urin sapi mengandung zat perangsang tumbuh yang dapat digunakan sebagai pengatur tumbuh diantaranya IAA. Lebih lanjut dijelaskan bahwa urin sapi juga memberikan pengaruh positif terhadap pertumbuhan vegetatif tananaman. Karena baunya yang khas, urin sapi juga dapat mencegah datangnya berbagai hama tanaman, sehingga urin sapi juga dapat berfungsi sebagai pengendalian hama serangga (Ahmad, 2012).

Dari beberapa penelitian menyebutkan bahwa urin sapi memiliki kandungan unsur kimia yang lebih banyak dari kotoran sapi padat. Kandungan urine sapi diantaranya : Nitrogen (N) 1,4 -22 \%, Fosfor (P) 0,6-0,7 \%, Kalium (K) 1,6-2,1\% (Ahmad, 2012).

Pengolahan tanah dimaksudkan untuk menjaga aerasi dan kelembaban tanah sesuai dengan kebutuhan tanah, sehingga pertumbuhan akar dan penyerapan unsur hara oleh akar tanaman dapat berlangsung dengan baik. Ada beberapa cara pengolahan tanah yang dapat dikelompokkan menjadi 3 yaitu tanpa olah tanah, pengolahan tanah minimum dan pengolahan tanah intensif (Tyasmoro et al, 1995).

Pada sistem tanpa olah tanah yang terus menerus, residu organik dari tanaman sebelumnya mengumpul pada permukaan tanah, sehingga terdapat aktivitas mikroba perombak tanah pada permukaan tanah yang lebih besar pada tanah-tanah tanpa olah jika dibandingkan dengan pengolahan tanah sempurna (Engelstad, 1997) Pengolahan tanah minimum atau tanpa olah tanah selalu berhubungan dengan penanaman yang cukup menggunakan tugal atau alat lain yang sama sekali tidak menyebabkan lapisan olah menjadi rusak dan di permukaan tanah masih banyak dijumpai residu tanaman. Residu tanaman yang banyak dipermukaan tanah tidak sampai mengganggu perkecambahan dan pertumbuhan benih (Sutanto, 2002).

Keadaan fisik tanah yang baik dapat memperbaiki lingkungan perakaran tanaman dan secara tidak langsung memudahkan penyerapan unsur hara sehingga keadaan tersebut menguntungkan untuk tanaman terung, sedangkan untuk sifat fisik tanah yang dapat diperbaiki dengan pengolahan tanah adalah aerasi tanah dan struktur tanah (Sutanto, 2002).

\section{METODE PENELITIAN}

Penelitian dilaksanakan di kebun warga Kecamatan Tangse Kabupaten Pidie. Bahan yang digunakan adalah urin sapi, benih terung ungu cap panah merah varietas YUMI F1, plastik PE, pupuk kandang, air serta kelengkapan lain dalam menunjang penelitian. Penelitian ini menggunakan Rancanagan Acak Kelompok (RAK) pola faktorial, yang terdiri dari 2 faktor yaitu faktor pertama sistem olah tanah (T) yang terdiri dari 3 taraf; $\mathrm{T}_{0}=$ tanpa olah tanah, $\mathrm{T}_{1}=$ olah tanah minimum, $\mathrm{T}_{2}=$ olah tanah konvensional, dan faktor kedua aplikasi urin sapi (U) yang terdiri dari 4 taraf; $\mathrm{U}_{0}=0 \mathrm{cc} / \mathrm{l}$ air, $\mathrm{U}_{1}=20 \mathrm{cc} / \mathrm{l}$ air, $\mathrm{U}_{2}=40 \mathrm{cc} / \mathrm{l}$ air, $\mathrm{U}_{3}=60$ 
cc/l air. Terdapat 12 kombinasi perlakuan dan 3 ulangan dengan keseluruhan diperoleh 36 satuan perlakuan

\section{HASIL DAN PEMBAHASAN Pengaruh Sistem Olah Tanah Tinggi Tanaman}

Faktor sistem olah tanah berpengaruh nyata terhadap tinggi tanaman terung ungu pada umur 20 dan 60 HST, namun berpengaruh tidak nyata pada umur $20 \mathrm{HST}$, dapat dilihat pada tabel berikut;

\begin{tabular}{cccc} 
Sistem Olah & \multicolumn{3}{c}{ Tinggi Tanaman $(\mathrm{cm})$} \\
\cline { 2 - 4 } Tanah & $20 \mathrm{HST}$ & $40 \mathrm{HST}$ & $60 \mathrm{HST}$ \\
\hline $\mathrm{T}_{0}$ & $21,08 \mathrm{a}$ & 35,21 & $67,25 \mathrm{a}$ \\
$\mathrm{T}_{1}$ & $22,00 \mathrm{a}$ & 35,46 & $68,71 \mathrm{a}$ \\
$\mathrm{T}_{2}$ & $22,21 \mathrm{~b}$ & 36,33 & $74,54 \mathrm{~b}$ \\
\hline BNJ 0,05 & 1,03 & - & 5,90 \\
\hline
\end{tabular}

Keterangan: Angka yang diikuti huruf yang sama pada kolom yang sama tidak berbeda nyata pada taraf $=5 \%(\mathrm{Uji}$ BNJ

Olah tanah menghasilkan pertumbuhan yang baik karena membentuk kondisi optimum bagi pertumbuhan tanaman. Olah tanah menciptakan struktur dan aerasi tanah lebih baik dibanding tanpa olah tanah. Olah tanah akan menyebabkan perkembangan akar tanaman lebih baik sehingga kemampuan akar menyerap unsur hara, air dan $\mathrm{O}_{2}$ lebih besar. Tanaman dalam pertumbuhannya memerlukan cukup $\mathrm{O}_{2}$ untuk respirasi. Jika rata-rata masukan $\mathrm{O}_{2}$ ke permukaan tanah terbatas maka pertumbuhan tanaman akan terhambat. Olah tanah sangat berpengaruh pada aerasi tanah dengan besarnya perubahan pada keadaan tanah awal. Olah tanah pada tanah padat dengan aerasi yang miskin dapat memperbaiki masalah aerasi secara berangsur-angsur (Pratama, 2011).

Dengan bajak, tanah akan menjadi gembur (struktur tanah hancur) dan porositas tanah menjadi lebih baik sehingga kemampuan tanah dalam meloloskan air menjadi tinggi, nilai porositas tanah berbanding lurus dengan nilai permeabilitas tanah, intinya semakin besar nilai porositas tanah maka semakin tinggi nilai permeabilitas tanah (Al Hadi, dkk, 2012).

\section{Jumlah Buah Per Plot}

Faktor sistem olah tanah berpengaruh sangat nyata terhadap jumlah buah per plot tanaman terung ungu, dapat dilihat pada tabel berikut;

\begin{tabular}{cc}
\hline $\begin{array}{c}\text { Sistem Olah } \\
\text { Tanah }\end{array}$ & Jumlah Buah Per Plot (Buah) \\
\hline $\mathrm{T}_{0}$ & $15,42^{\mathrm{a}}$ \\
$\mathrm{T}_{1}$ & $16,58^{\mathrm{a}}$ \\
$\mathrm{T}_{2}$ & $19,83^{\mathrm{b}}$ \\
\hline BNJ 0.05 & 2,79 \\
\hline
\end{tabular}

Keterangan: Angka yang diikuti huruf yang sama pada kolom yang sama tidak berbeda nyata pada taraf $=5 \%(\mathrm{Uji} B N J)$

Dalam jangka pendek pengolahan tanah intensif bersifat positif bagi tanaman, pengolahan tanah secara berlebih dalam waktu lama akan menimbulkan dampak negatif terhadap produktivitas lahan. Pengolahan tanah merupakan kegiatan yang paling banyak memerlukan energi, sehingga harus dilakukan dengan perencanaan baik. Sebab kesalahan dalam pengolahan tanah dapat merusak struktur tanah, mempercepat terjadi erosi, terjadinya perombakan bahan organik dengan cepat dan memadatkan tanah (Al Hadi, dkk, 2012).

Pengolahan tanah secara intensif yang dilakukan pada setiap musim tanam akan 
JAR,Volume 4 Nomor 1 April 2021

p-ISSN 2615-417X, e-ISSN 2721-0782

DOI : https://doi.org/10.47647/jar

memacu terjadinya erosi dikarenakan struktur tanah yang gembur dan akan menyebabkan menurunnya kesuburan tanah akibat dari terjadinya pencucian sejumlah unsur hara yang terkandung di dalam tanah (Rachman et al., 2004).

Olah tanah juga memperbaiki struktur tanah menjadi lebih remah sehingga akar tanaman dapat tumbuh dengan berkembang dengan optimal (Raifuddin et al, 2006).

\section{Berat Buah Per Plot}

Faktor sistem olah tanah berpengaruh sangat nyata terhadap berat buah per plot terung ungu, dapat dilihat pada tabel berikut;

Sistem Olah Tanah Berat Buah Per Plot $(\mathrm{Kg})$

\begin{tabular}{cc}
\hline $\mathrm{T}_{0}$ & $1,61^{\mathrm{a}}$ \\
$\mathrm{T}_{1}$ & $1,7^{\mathrm{a}}$ \\
$\mathrm{T}_{2}$ & $2,20^{\mathrm{b}}$ \\
\hline BNJ 0.05 & 0,33
\end{tabular}

Keterangan : Angka yang diikuti huruf yang sama pada kolom yang sama tidak berbeda nyata pada taraf $=5 \%$ (Uji BNJ)

Olah tanah maksimum memberikan hasil yang lebih tinggi dibanding tanpa olah tanah. Hubungannya dengan sifat fisik tanah ialah perbaikan pertumbuhan tanaman pada tanah diolah disebabkan karena olah tanah menurunkan berat isi tanah sehingga meningkatkan porositas tanah. Akibatnya sistem perakaran tanaman menjadi lebih baik sehingga absorbsi unsur hara lebih sempurna dan tanaman dapat tumbuh dan memberi hasil yang lebih tinggi (Pratama, 2011).

\section{Pengaruh Urin Sapi Tinggi Tanaman}

Faktor urin sapi berpengaruh tidak nyata terhadap tinggi tanaman terung ungu pada umur 20, 40 dan 60 HST, dapat dilihat pada tabel berikut;

\begin{tabular}{cccc}
\hline \multirow{2}{*}{ Urin Sapi } & \multicolumn{3}{c}{ Tinggi Tanaman $(\mathrm{cm})$} \\
\cline { 2 - 4 } & $20 \mathrm{HST}$ & $40 \mathrm{HST}$ & $60 \mathrm{HST}$ \\
\hline $\mathrm{U}_{0}$ & 21,56 & 35,56 & 66,22 \\
$\mathrm{U}_{1}$ & 21,94 & 35,00 & 69,94 \\
$\mathrm{U}_{2}$ & 21,28 & 36,72 & 71,11 \\
$\mathrm{U}_{3}$ & 12,53 & 19,91 & 41,28 \\
\hline
\end{tabular}

Pemberian dosis urin sapi yang lebih tinggi menyebabkan penurunan pertumbuhan, karena akan menyebabkan $\mathrm{pH}$ tanah menjadi tinggi sehingga tanah menjadi masam dan hal itu akan menyebabkan tekanan akar menjadi lebih besar dari pada tekanan dari tanah. Unsur hara mudah diserap akar tanaman pada $\mathrm{pH}$ tanah sekitar netral karena pada $\mathrm{pH}$ tersebut kebanyakan hara mudah larut dalam air (Hendra, 2007).

\section{Jumlah Buah per plot}

Faktor urin sapi berpengaruh sangat nyata terhadap jumlah buah per plot tanaman terung ungu, dapat dilihat pada tabel berikut;

\begin{tabular}{cc}
\hline Urin Sapi & Jumlah Buah Per Plot (buah) \\
\hline $\mathrm{U}_{0}$ & $13,67^{\mathrm{a}}$ \\
$\mathrm{U}_{1}$ & $19,78^{\mathrm{c}}$ \\
$\mathrm{U}_{2}$ & $16,11^{\mathrm{b}}$ \\
$\mathrm{U}_{3}$ & $11,00^{\mathrm{a}}$ \\
\hline BNJ 0,05 & 3,57
\end{tabular}

Keterangan : Angka yang diikuti huruf yang sama pada kolom yang sama tidak berbeda nyata pada taraf $=5 \%(\mathrm{Uji} \mathrm{BNJ})$

Setiap tanaman dengan dosis yang diberikan akan mempengaruhi besar kecilnya kandungan hara dalam pupuk tersebut, tetapi belum dapat dijamin bahwa semakin besar dosis yang diberikan akan semakin meningkatkan pertumbuhan tanaman. Sebab 
JAR,Volume 4 Nomor 1 April 2021

p-ISSN 2615-417X, e-ISSN 2721-0782

DOI : https://doi.org/10.47647/jar

tanaman juga memiliki batas dalam penyerapan hara untuk kebutuhan hidupnya (Kasniari dan Supadma ,2007). Pemberian pupuk konsentrasi tinggi sampai batas tertentu akan menyebabkan hasil semakin meningkat, dan pada konsentrasi yang melebihi batas tertentu pula akan menyebabkan hasil menjadi menurun dan juga tanaman akan tumbuh dengan baik apabila unsur hara yang diberikan berada dalam jumlah yang seimbang dan sesuai dengan kebutuhan tanaman (Mappanganro $\mathrm{N}$, dkk., 2011).

\section{Berat Buah Per plot}

Faktor urin sapi berpengaruh sangat nyata terhadap berat buah per plot terung ungu, dapat dilihat pada tabel berikut;

\begin{tabular}{cc}
\hline Urin Sapi & Berat Buah Per Plot $(\mathrm{Kg})$ \\
\hline $\mathrm{U}_{0}$ & $1,50^{\mathrm{a}}$ \\
$\mathrm{U}_{1}$ & $1,83^{\mathrm{b}}$ \\
$\mathrm{U}_{2}$ & $1,77^{\mathrm{b}}$ \\
$\mathrm{U}_{3}$ & $1,31^{\mathrm{a}}$ \\
\hline BNJ 0,05 & 0,38 \\
\hline
\end{tabular}

Keterangan : Angka yang diikuti huruf yang sama pada kolom yang sama tidak berbeda nyata pada taraf $=5 \%$ (Uji BNJ)

Urin sapi mengandung unsur $\mathrm{K}$ sebesar 0,329\%. Unsur $\mathrm{K}$ berperan sebagai kofaktor dalam sintesis protein, keseimbangan air, dan pergerakan stomata. Stomata merupakan pintu keluar masuk $\mathrm{CO}_{2}$ sebagai bahan fotosintesis. Stomata yang mampu memasukkan banyak $\mathrm{CO}_{2}$ akan dihasilkan banyak fotosintat yang dapat digunakan untuk pertumbuhan organ tanaman yang diekspresikan berupa bobot kering tanaman (Rosniawaty, et al., 2015).

Pertumbuhan tanaman ditunjukkan dengan penambahan ukuran bobot kering yang mencerminkan bertambahnya protoplasma karena ukuran maupun jumlah sel bertambah. Untuk mendapatkan pertumbuhan tanaman yang optimal, membutuhkan pemberian pupuk dengan dosis dan cara pemberian yang tepat. Jika pupuk organik cair diberikan langsung tanpa pengenceran dapat berdampak kurang baik terhadap pertumbuhan tanaman. Apabila pupuk langsung mengenai perakaran maka tanaman akan mengalami plasmolisis yang menyebabkan kelayuan (Harjadi, 2002).

\section{KESIMPULAN}

Sistem olah tanah berpengaruh nyata terhadap tinggi tanaman umur 20 dan 60 HST dan berpengaruh sangat nyata terhadap jumlah buah per plot dan berat buah per plot serta berpengaruh tidak nyata terhadap tinggi tanaman umur $40 \mathrm{HST}$. Sistem olah tanah yang terbaik dijumpai pada perlakuan sistem olah tanah konvensional.

Urin sapi berpengaruh sangat nyata terhadap jumlah buah per plot dan berat buah per plot, berpengaruh tidak nyata terhadap tinggi tanaman. Urin sapi yang terbaik dijumpai pada perlakuan konsentrasi urin sapi $20 \mathrm{cc} / \mathrm{L}$ air.

\section{DAFTAR PUSTAKA}

Ahmad. 2012. Pupuk Organik Dari Urine Sapi. Kanisius, Yogyakarta.

Al Hadi, B., Yunus, Y., Idkham, M. Juni. 2012. Analisis Sifat Fisika Tanah Akibat Lintasan dan Bajak Traktor Roda Empat. Jurnal Manajemen Sumberdaya Lahan. Vol. 1, No. 1. 43-53.

Engelstad, O.P. 1997. Teknologi dan Penggunaan Pupuk (diterjemahkan oleh Didiek H.G). Gadjah Mada 
JAR,Volume 4 Nomor 1 April 2021

p-ISSN 2615-417X, e-ISSN 2721-0782

DOI : https://doi.org/10.47647/jar

University Press. Yogyakarta. 799 hal.

Firmanto, B. 2011.Sukses Bertanaman Terung Secara Organik. Angkasa, Bandung.

Harjadi, S.S. 2002. Pengantar Agronomi. PT Gramedia Pustaka Utama. Jakarta.

Hendra, A. 2007. Pengaruh Konsentrasi Kapur Danalum Terhadap Karakteristik Limbah Cair Industri Tahu dalam Pengolahan Pendahuluan. Skripsi Sarjana. Fakultas Teknik. Universitas Lampung. Bandar Lampung.

Kasniari D.N. dan Supadma N 2007,. Pengaruh Pemberian Beberapa Dosis Pupuk (N, P, K) dan Jenis Pupuk Alternatif terhadap Hasil Tanaman Padi (Oryza sativa L.) dan Kadar N, P, K Inceptisol Selemadeg, Tabanan. Fakultas Pertanian Universitas Udayana.

Mappanganro, N., Enny, L. S. dan Baharuddin. 2011. Pertumbuhan dan Produksi Tanaman Stroberi pada berbagai Jenis dan Konsentrasi Pupuk Organik Cair dan Urine Sapi dengan Sistem Hidroponik Irigasi Tetes. (Online), (http://pasca.unhas.ac.idjurnalfiles0064 cfe0e9cfeb14c69b7f0662b4772a.pdf diakses 28 Maret 2015).

Nazaruddin. 2001, Pupuk Cair Supermes, Penebar Swadaya, Jakarta.

Pratama, V.N. 2011. Pengaruh sistem olah tanah dan aplikasi berbagai dosis herbisida pra tanam terhadap pertumbuhan dan hasil kedelai (Glycine max L.). Skripsi Jurusan Budidaya Pertanian. FP-UB (unpublished).

Rachman, A., U. Kurnia, dan A. Dariah. 2004. Teknologi Konservasi Tanah pada Lahan Kering Berlereng. Pusat Pengembangan dan Penelitian Tanah dan Agroklimat. Jawa Barat. Hlm 183- 201.

Raifuddin, R. Padjung dan M. Tandi. 2006. Efek sistem olah tanah dan super mikro hayati terhadap pertumbuhan dan produksi jagung. J. Agrivigor 5 (3): 239-246.

Rosinawaty, S., Sudirja, R., \& Afrianto, H. 2015. Pemanfaatan Urine Kelinci dan Urine Sapi sebagai Alternatif Pupuk Organik Cair Pada Pembibitan Kakao (Theobrome caco L.). Jurnal Kultivasi, 14 (1): 32-36.

Sunarjono, H. 2013. Bertanam 36 Jenis Sayur. Penebar Swadaya, Jakarta.

Sutanto Rachman. 2002. Pertanian Organik: Menuju Pertanian Alternatif Dan Berkelanjutan. Jakarta: Kanisius

Tyasmoro, S.T., B. Suprayoga dan A. Nugroho. 1995. Cara Pengelolaan Lahan Yang Berwawasan Lingkungan Dan Budidaya Tanaman Sebagai Upaya Konservasi Tanah Di DAS Brantas Hulu. Pros. Seminar Nasional V : 9 - 14. 